\title{
Hubungan antara efikasi diri dengan keterampilan komunikasi siswa
}

\author{
Budi Astuti* \& Anggi Idwar Pratama \\ Program Studi Bimbingan dan Konseling, Pascasarjana, Universitas Negeri Yogyakarta \\ Jl. Colombo No 1, Karangmalang, Caturtunggal, Depok, Sleman, Daerah Istimewa Yogyakarta \\ *Corresponding Author. e-mail: budi_astuti@uny.ac.id; anggiidwar.2018@student.uny.ac.id
}

\begin{abstract}
Abstrak
Penelitian ini bertujuan untuk mengetahui hubungan antara efikasi diri dan keterampilan komunikasi siswa. Metode penelitian yang digunakan adalah pendekatan kuantitatif dengan jenis penelitian korelasional. Populasi pada penelitian ini ialah siswa SMP Islam Al Azhar 26 Yogyakarta kelas VII A, VII B, VII C, VIID, VII E, VII F dan VII G. Penelitian ini melibatkan seluruh populasi siswa kelas VII dengan jumlah 124 siswa. Teknik pengumpulan data menggunakan skala efikasi diri dan skala keterampilan komunikasi yang diadaptasi. Realibilitas skala efikasi diri 0,91 dan realibillitas skala keterampilan komunikasi 0,89 . Hasil penelitian menunjukkan bahwa terdapat hubungan positif dan signifikan antara efikasi diri dengan keterampilan komunikasi siswa. Hasil korelasi diperoleh 0.208 yang berada pada koefesien korelasi antara 0.20-0.399 termasuk memiliki tingkat hubungan rendah. Masih ada faktor-faktor lain yang memiliki hubungan dengan keterampilan komunikasi. Tingkat efikasi diri siswa termasuk dalam kategori sedang sebanyak 94 siswa (76\%). Tingkat keterampilan komunikasi siswa termasuk dalam kategori sedang sebanyak 82 siswa (66\%). Hasil penelitian ini memberikan implikasi terhadap guru bimbingan dan konseling untuk memberikan intervensi-intervensi yang tepat agar keterampilan komunikasi siswa dapat meningkat dengan efikasi diri yang memadai.
\end{abstract}

Kata Kunci: efikasi diri, keterampilan komunikasi, bimbingan dan konseling

\section{The relationship between self-efficacy and student communication skills}

\begin{abstract}
This study aimed to determine the relationship between self-efficacy and student communication skills. The research method used is a quantitative approach to the type of correlational research. The population in this study were students of Al Azhar 26 Yogyakarta Islamic Middle School class VII A, VII B, VII C, VIID, VII E, VII F and VII G. This study involved the entire population of grade VII students with a total of 124 students. Data collection techniques using self-efficacy scales and communication skills scales were adapted. The reliability of the self-efficacy scale was 0.91 and the reliability of the communication skills scale was 0.89. The results showed that there was a positive and significant relationship between selfefficacy and student communication skills. The correlation results obtained 0.208 which is at the correlation coefficient between 0.20-0.399 at the low level of relationship. There are still other factors that have a relationship with communication skills. The level of student self-efficacy is included in the moderate category of 94 students (76\%). The level of student communication skills is included in the moderate category of 82 students (66\%). The results of this study have implications for teacher guidance and counseling to provide appropriate interventions so that students' communication skills can be improved with adequate self-efficacy.
\end{abstract}

Keywords: self-efficacy, communication skills, guidance, and counseling

How to Cite: Astuti, B., \& Pratama, A. I. (2020). Hubungan antara efikasi diri dengan keterampilan komunikasi siswa. Jurnal Penelitian Ilmu Pendidikan, 13(2), 147-155. doi: https://doi.org/10.21831/jpipfip.v13i2.33757

Received 05-08-2020; Received in revised from 31-08-2020; Accepted 06-09-2020

This is an open-access article under the CC-BY-SA license. 
Jurnal Penelitian Ilmu Pendidikan, 13 (2), 2020 - 148

Astuti \& Pratama

\section{PENDAHULUAN}

Pendidikan di sekolah merupakan suatu proses yang melibatkan pendidik dan siswa. Dalam UU No 20 tahun 2003 tentang Sistem Pendidikan Nasional tercantum pada bab 1 pasal 20 yaitu pembelajaran adalah proses interaksi siswa dengan pendidik pada suatu lingkungan belajar. Lingkungan sekolah sangat besar dampaknya dalam proses pendidikan (Depdiknas, 2003). Lingkungan sekolah dapat mempengaruhi motivasi belajar, kedisiplinan siswa, hasil belajar dan minat belajar siswa (Rahmawati, 2014, Andriana, 2017, Khasanah, 2016, Kurniawan, 2013 dan Khanifah, et. al, 2012). Di lingkungan sekolah, siswa tidak akan terlepas dari sebuah proses komunikasi. Komunikasi merupakan cara siswa memperlihatkan rasa senang berbicara, bergaul, dan bekerja sama dengan orang lain (Kemendiknas, 2010). Siswa akan terus melakukan komunikasi untuk mencari informasi, untuk bertanya dan aktif ketika kegiatan belajar berlangsung. Di dalam proses pembelajaran dikatakan bahwa proses komunikasi, menunjuk pada proses penyampaian pesan dari seseorang sebagai sumber pesan (guru) kepada penerima pesan (siswa) (Sumantri, 2015:349).

Komunikasi dalam pembelajaran merupakan proses pertukaran informasi berupa materi pembelajaran antara guru dan siswa (Pal, et. al, 2016), Chung, et. al, 2014). Komunikasi sangat berperan dalam proses pembelajaran yang bertujuan untuk mentransfer pengetahuan dan pertukaran ide atau gagasan (Sharifirad, et. al, 2012). Komunikasi merupakan cara siswa untuk berinteraksi dengan orang lain. Komunikasi menentukan kualitas dari seseorang tersebut. Komunikasi tidak hanya sekedar berkomunikasi, komunikasi memerlukan keterampilan. Keterampilan (skills) merupakan kemampuan untuk mengoperasikan pekerjaan secara mudah dan cermat (Widiastuti \& Muktiana, 2010:49). Komunikasi lebih bersifat pribadi dan memerlukan adanya keterbukaan, kemampuan memahami dan mendengarkan dengan penuh empati, mampu mengungkapkan pernyataan serta mampu melakukan umpan balik secara baik. Selain itu, individu mempunyai kemampuan mawas diri dan mampu melihat diri sendiri dengan cara bagaimana orang melihat dirinya (Basuki, 2013). Komunikasi memerlukan keterampilan agar bisa berkomunikasi secara efektif. Keterampilan komunikasi sangat diperlukan untuk menyampaikan ide, gagasan, dan pengetahuan. Keterampilan komunikasi mempunyai hubungan sangat signifikan dengan aktivitas belajar. Dengan dimilikinya keterampilan komunikasi menjadikan siswa dengan mudah dapat menyelesaikan pekerjaannya. Semakin baik keterampilan komunikasi siswa, maka semakin baik aktivitas belajarnya. Sebaliknya, semakin tidak baik keterampilan komunikasi maka semakin tidak baik pula aktivitas belajarnya (Maryanti, Zikra \& Nurfarhanah, 2013). Keterampilan komunikasi merupakan kemampuan siswa untuk mengadakan hubungan melalui komunikasi atau media sehingga dapat dipahami dengan baik (Chatab, 2007:29). Cangara (2008:85) menjelaskan keterampilan komunikasi adalah kemampuan seseorang untuk menyampaikan atau mengirim pesan kepada khalayak (penerima pesan). Pembelajaran yang aktif dapat terlaksana dengan baik apabila siswa memiliki keterampilan komunikasi (Slavin, 2018).

Kenyataannya, masih terdapat permasalahan sehubungan dengan keterampilan komunikasi siswa yang masih tergolong belum optimal. Penelitian Kamaruzzaman (2016) mengungkap hasil analisis berupa keterampilan komunikasi interpersonal siswa dalam kategori cukup $(47,15 \%)$. Demikian juga, Musliah, et. al, (2015) menemukan keterampilan komunikasi siswa tergolong cukup $(66,77 \%)$. Kemampuan siswa dalam mengajukan pertanyaan termasuk kategori cukup $(43,75 \%)$, dengan indikasi terdapat beberapa siswa masih malu untuk memberikan tanggapan dan mengajukan pertanyaan ketika menemui jawaban berbeda dari hasil diskusi dengan kelompok lain (Wati, et. al, 2019). Keterampilan komunikasi siswa yang belum optimal ini, nampaknya menjadi perhatian pihak sekolah untuk meningkatkannya. Peran guru bimbingan dan konseling menjadi penting. Siswa perlu mendapatkan layanan bimbingan dan konseling dengan strategi yang tepat dari guru bimbingan dan konseling agar keterampilan komunikasi siswa meningkat.

Pada saat proses pembelajaran berlangsung, siswa tidak mudah untuk bisa menyampaikan ide ataupun gagasan yang dimilikinya karena tidak mempunyai keterampilan komunikasi yang memadai. Siswa membutuhkan keberanian, keyakinan dan optimisme untuk menyampaikan gagasan dan ide-ide. Siswa yang tidak memiliki keberanian untuk menyampaikan gagasan akan menyebabkan mereka menjadi pasif, merasa malu, tidak percaya diri dan merasa insecure. Faktorfaktor yang mempengaruhi komunikasi diantaranya faktor psikologis, fisik, semantik, dan proses 
penyampaian pesan. Faktor psikologis meliputi rasa takut, malu, dan kurang percaya diri ketika bertanya atau perpendapat (Urwani, A. N., Ramli, M., \& Ariyanto, J, 2018). Faktor psikologis yang memuat kepercayaan diri siswa terkait dengan efikasi diri. Perasaan yakin akan kemampuan diri dalam efikasi diri dapat menumbuhkan semangat untuk belajar menjadi lebih baik. Efikasi diri berperan menentukan bagaimana seseorang melakukan pendekatan terhadap berbagai saran, tugas dan tantangan. Siswa yang merasa takut, cemas, biasanya memiliki efikasi diri rendah. Sementara itu, siswa yang memiliki efikasi diri tinggi, merasa mampu dan yakin terhadap kesuksesan dalam mengatasi rintangan dan menganggap ancaman sebagai suatu tantangan. Efikasi diri merupakan harapan serta keyakinan tentang seberapa kompeten siswa mampu melakukan perilaku dalam situasi tertentu (Friedman \& Schustack, 2016:172).

Efikasi diri berpengaruh dalam menentukan tindakan yang akan dilakukan untuk mencapai suatu tujuan, termasuk didalamnya prediksi kejadian yang akan dihadapi (Ghufron \& Risnawita, 2014:73). Myers (2010:56) menyatakan bahwa efikasi diri merupakan kebijakan dibalik kekuatan pada pikiran positif. Keyakinan yang optimis akan memiliki kemungkinan lebih besar untuk meraih keberhasilan dibandingkan keyakinan yang pesimis. Bandura (Handayani dan Nurwidawati, 2013) menguraikan efikasi diri terdiri dari tiga dimensi, yaitu: 1) Level/magnitude, yaitu berhubungan dengan taraf kesulitan tugas, 2) Strenghts, berkaitan dengan kekuatan mental yang dimiliki individu, 3) Generality, dimensi ini merupakan suatu konsep bahwa efikasi diri seorang dapat digunakan pada hal apapun, tidak hanya pada hal-hal tertentu.

Berdasarkan uraian tentang permasalahan keterampilan komunikasi siswa, belum diketahui hubungannya dengan faktor internal yaitu efikasi diri. Rumusan masalah dalam penelitian ini ialah apakah terdapat hubungan antara efikasi diri dengan keterampilan komunikasi siswa. Selaras dengan rumusan masalah, penelitian ini bertujuan untuk mengetahui hubungan antara efikasi diri dengan keterampilan komunikasi siswa.

\section{METODE}

Metode yang digunakan dalam penelitian ini adalah pendekatan kuantitatif dengan analisis data korelasional. Metode kuantitatif menekankan analisis pada data-data kuantitatif (angka) yang dikumpulkan melalui prosedur pengukuran dan diolah dengan metode analisis statistika. Jenis korelasional mengetahui kekuatan dan arah hubungan yang ada di antara variabel-variabel, melihat sejauh mana variasi pada satu variabel dengan variasi pada satu atau lebih variabel lain (Azwar, 2017:5). Penelitian ini melihat hubungan antara efikasi diri sebagai variabel independen (variabel bebas) dengan keterampilan komunikasi sebagai variabel terikat (variabel dependen). Populasi penelitian adalah seluruh siswa kelas VII SMP Islam Al azhar 26 Yogyakarta. Dalam penelitian ini seluruh populasi yaitu 124 siswa, terdiri dari kelas VII A, VII B, VII C, VIID, VII E, VII F, dan VIIG.

Teknik pengumpulan data dalam penelitian ini menggunakan skala efikasi diri dengan model skala likert. Skala efikasi diri diadaptasi dari Self-Efficacy in Intercultural Communication: The Development and Validation of a Sojouners' Scale (Peterson, J. C, et. al, 2011). Kuesioner terdiri dari 4 indikator dan 33 item pernyataan. Koefisien Alpha Crinbach dari seluruh skala dihitung dan menunjukkan skor 0,91. Skala berikutnya ialah skala keterampilan komunikasi yang diadaptasi dari Development and Validity-Realibility Study of Communication Skills Scale for Student Teacher: Suggestion of an Alternative Model (Akkuzu \& Akkaya, 2014). Skala keterampilan komunikasi terdiri dari 4 indikator dan 36 item pernyataan. Koefisien Alpha Cronbach dari seluruh skala dihitung dan menunjukkan skor 0,89 . Koefisien reliabilitas tergolong tinggi, sehingga skala dinyatakan andal dan item pernyataan skala dinyatakan homogen (Akkuzu \& Akkaya, 2014).

Pelaksanaan penelitian ini meliputi beberapa proses yaitu dengan mempersiapkan surat-surat penelitian yang diperlukan, mempersiapkan alat penelitian berupa skala yang telah disusun, peneliti kemudian melakukan uji coba untuk mengetahui apakah pernyataan yang digunakan dipahami oleh responden dan mengukur apa yang hendak diukur. Pengumpulan data menggunakan skala efikasi diri dan skala keterampilan komunikasi via google form yang dikirimkan kepada seluruh siswa melalui wali kelas masing-masing. 


\section{Jurnal Penelitian Ilmu Pendidikan, 13 (2), 2020 - 150}

Astuti \& Pratama

\section{HASIL DAN PEMBAHASAN}

\section{Hasil}

Hasil analisis korelasi yaitu hubungan antara efikasi diri dengan keterampilan komunikasi siswa, diperoleh koefisien korelasi sebesar $\mathrm{r}=0.208$ dengan $\mathrm{p}=0.02(\mathrm{p}<0.05)$ yang berarti bahwa arah korelasi dalam penelitian ini adalah berhubungan positif. Artinya, semakin tinggi efikasi diri siswa, semakin tinggi pula keterampilan komunikasi siswa, sebaliknya semakin rendah efikasi diri siswa, semakin rendah pula keterampilan komunikasi siswa. Namun demikian, hubungan kedua variabel tersebut tidak terlalu kuat, yang mana hubungan kedua variabel tersebut rendah, dilihat dari nilai koefesien korelasi menurut Sugiyono (2011:184) sebagai berikut.

Tabel 1. Pedoman Interpretasi Koefisien Korelasi

\begin{tabular}{cll}
\hline No & Interval Koefisien & \multicolumn{1}{c}{$\begin{array}{c}\text { Tingkat } \\
\text { Hubungan }\end{array}$} \\
\hline 1 & $0,00-0,199$ & Sangat rendah \\
2 & $0,20-0,399$ & Rendah \\
3 & $0,40-0,599$ & Sedang \\
5 & $0,60-0,799$ & Kuat \\
6 & $0,80-1.000$ & Sangat kuat \\
\hline
\end{tabular}

Berdasarkan tabel 1, hasil korelasi yang diperoleh 0.208 berada pada koefisien korelasi antara 0.20-0.399 berarti tingkat hubungan rendah. Hal itu terjadi karena masih ada faktor-faktor lain yang mempengaruhi atau memiliki hubungan dengan keterampilan komunikasi siswa selain efikasi diri. Adapun hasil pengujian hipotesis dalam penelitian ini adalah Ha diterima dan Ho ditolak.

Tabel 2. Rerata Empiris dan Rerata Hipotetik Efikasi Diri dan Keterampilan Komunikasi

\begin{tabular}{lllllllll}
\hline Variabel & \multicolumn{3}{c}{ Skor hipotesis } & \multicolumn{4}{c}{ Skor empiris } \\
\cline { 2 - 4 } & Min & Max & Mean & Sd & Min & Max & Mean & Sd \\
\hline Efikasi diri & 81 & 126 & 99 & 10.053 & 33 & 165 & 99.97 & 22 \\
Keterampilan komunikasi & 62 & 121 & 108 & 8.728 & 36 & 180 & 98.83 & 24 \\
\hline
\end{tabular}

Berdasarkan tabel 2 tersebut diketahui bahwa rerata empiris dan rerata hipotetik berkaitan antara efikasi diri dan keterampilan komunikasi. Rangkuman data penelitian di atas digunakan oleh peneliti untuk mengkategorisasikan efikasi diri siswa dan keterampilan komunikasi siswa.

Berdasarkan tabel 2 rerata empiris, efikasi diri siswa rata-rata sebesar 99.97 sedangkan rerata hipotetik efikasi diri siswa sebesar 99. Hal ini menunjukkan bahwa secara umum rerata empiris siswa lebih besar daripada hipotetik penelitian, artinya rerata siswa lebih besar dibandingkan populasi pada umumnya. Berdasarkan skala keterampilan komunikasi, rerata empiris keterampilan komunikasi siswa rata-rata sebesar 98.83, sedangkan rerata hipotesis 108. Hal ini menunjukkan bahwa keterampilan komunikasi siswa memiliki kategorisasi lebih kecil daripada populasiumumnya.

Tabel 3. Hasil Skor Kategorisasi Variabel Efikasi Diri

\begin{tabular}{ccccc}
\hline Variabel & Skor & Kategori & \multicolumn{3}{c}{ Subjek } \\
\hline Efikasi Diri & $\mathrm{X} \leq 66$ & Sangat & 0 & 0 \\
& Rendah & & \\
& $72<\mathrm{X} \leq 88$ & Rendah & 9 & 7 \\
& $96<\mathrm{X} \leq 110$ & Sedang & 94 & 76 \\
& $120 \mathrm{X} \leq 132$ & Tinggi & 21 & 17 \\
& $132<\mathrm{X}$ & Sangat Tinggi & 0 & 0 \\
\hline Total & & 124 & 100 \\
\hline
\end{tabular}

Kemudian peneliti mengkategorisasikan efikasi diri secara keselurhan seperti Tabel 3. Hasil analisis secara keseluruhan efikasi diri pada 124 siswa berada dalam kategorisasi sedang, yaitu sebanyak 94 siswa $(76 \%)$, tidak ada siswa dalam kategori sangat rendah (0\%), 9 siswa dalam kategori rendah (7\%), 21 siswa dalam kategori tinggi (17\%) dan tidak ada siswa yang memiliki efikasi diri dalam kategori sangat tinggi 
Jurnal Penelitian Ilmu Pendidikan, 13 (2), 2020 - 151

Astuti \& Pratama

$(0 \%)$.

Tabel 4. Hasil Skor Kategorisasi Variabel Keterampilan Komunikasi

\begin{tabular}{|c|c|c|c|c|}
\hline \multirow[t]{2}{*}{ Variabel } & \multirow[t]{2}{*}{ Skor } & \multirow[t]{2}{*}{ Kategori } & \multicolumn{2}{|c|}{ Subjek } \\
\hline & & & $\mathrm{F}$ & Persentase (\%) \\
\hline \multirow{6}{*}{$\begin{array}{c}\text { Keterampilan } \\
\text { komunikasi }\end{array}$} & $\mathrm{X} \leq 72$ & Sangat Rendah & 1 & 1 \\
\hline & $72<X \leq 96$ & Rendah & 40 & 32 \\
\hline & $96<X \leq 120$ & Sedang & 82 & 66 \\
\hline & $120 X \leq 144$ & Tinggi & 1 & 1 \\
\hline & $144<X$ & Sangat tinggi & 0 & 0 \\
\hline & Total & & 124 & 100 \\
\hline
\end{tabular}

Variabel keterampilan komunikasi dikategorisasikan secara keseluruhan. Hasil analisis secara keseluruhan keterampilan komunikasi pada 124 siswa, terdapat 82 siswa dengan kategori sedang (66)\%, 1 siswa dengan kategori sangat rendah (1\%), 40 siswa dengan kategori rendah (32\%), 1 siswa dengan kategori tinggi (1\%), dan 0 siswa dengan kategori sangat tinggi (0\%).

\section{Pembahasan}

Penelitian ini bertujuan untuk mengetahui hubungan antara efikasi diri dengan keterampilan komunikasi siswa. Hasil penelitian menunjukkan bahwa dari hasil uji korelasi terdapat hubungan yang positif dan signifikan antara efikasi diri dengan keterampilan komunikasi siswa. Hal ini menunjukkan bahwa semakin tinggi efikasi diri siswa maka semakin tinggi keterampilan komunikasi (Tingginehe \& Wijono, 2018). Efikasi diri mempunyai pengaruh signifikan terhadap komunikasi antar pribadi. Hal ini menunjukkan bahwa efikasi diri tinggi akan berpengaruh pada komunikasi siswa (Handani \& Soekirno, 2020 \& Myers \& Eike, 2020). Akan tetapi, nilai efikasi diri siswa berada pada koefisien korelasi antara 0.20-0.399 berada pada tingkat hubungan rendah. Ini menunjukkan masih ada faktor-faktor lain yang memiliki hubungan dengan keterampilan komunikasi. Faktor-faktor yang berhubungan dengan keterampilan komunikasi diantaranya: sumber, encoding, pesan, saluran, penerima, decoding, respon, gangguan dan konteks komunikasi (ruang, waktu, nilai), serta unsur budaya (Suhanti, et. al, 2018). Aw (2011:7) mengatakan bahwa komunikasi tidak terlepas dari unsur-unsur seperti: 1) komunikator, merupakan orang yang mempunyai kebutuhan untuk berkomunikasi; 2) encoding, tindakan memformulasikan isi pikiran ke dalam simbol-simbol; 3) pesan, simbol-simbol verbal dan nonverbal atau gabungan keduanya; 4) saluran, merupakan saran fisik penyampaian pesan dari sumber ke penerima; 5) komunikan, merupakan orang yag menerima dan 6) decoding, penerima mendapatkan macam-macam data dalam bentuk mentah, berupa kata-kata dan simbol-simbol.

Hasil penelitian ini sesuai dengan penelitian Kharisma (2019) yang menunjukkan bahwa terdapat hubungan positif yang signifikan antara efikasi diri dengan komunikasi. Akan tetapi, kontribusi keterampilan komunikasi yang dibentuk oleh efikasi diri hanya sebesar 28,0\%. Efikasi diri memberikan kontribusi untuk meningkatkan keterampilan komunikasi tetapi tidak terlalu besar. Faktor-faktor lain diperlukan untuk meningkatkan keterampilan komunikasi, selain efikasi diri. Faktorfaktor lain tersebut diantaranya dijelaskan oleh Kusmiarti, Yuniati, \& Noermanzah (2020) yaitu kemampuan intelektual kematangan emosi, kematangan sosial, dan kemampuan problem solving.

Efikasi diri mempunyai hubungan dengan kecemasan ketika berkomunikasi (Musyafa, 2017, Deviyanti, 2016, Tonglo, 2004, Wahyuni, 2015, Jendra, et. al, 2020 dan Permana, et. al, 2016). Efikasi diri memiliki peran yang baik agar dapat memberikan pengaruh positif terhadap kemampuan komunikasi baik secara verbal dan non verbal. Efikasi diri yang baik dapat menjadi sumber motivasi internal untuk meningkatkan kepercayaan diri secara aktif dan lebih komunikatif. Efikasi diri yang baik memberikan pengaruh yang positif terhadap iklim organisasi untuk dapat kondusif dalam mengembangkan ilmu pengetahuan, teknologi dari hasil riset yang dihasilkan (Romadona, 2017).

Guru bimbingan dan konseling harus dapat meningkatkan keterampilan komunikasi siswa salah satunya dengan meningkatkan efikasi diri siswa. Sesuai dengan penelitian yang dilakukan oleh 
Wardani, (2012), Suseno (2009) \& Ashfia (2018), hasil penelitian menunjukkan bahwa subjek mengalami peningkatan efikasi diri dalam kemampuan komunikasi setelah dilakukan pelatihan dan efikasi diri menjadikan komunikasi lebih berkualitas. Siswa juga harus memperhatikan beberapa faktor ketika komunikasi, seperti mengenal diri sendiri, kepercayaan (credibility), daya tarik (attractiveness) dan kekuatan (power) (Cangara, 2019:113). Efikasi diri saja tidak cukup untuk melakukan komunikasi, karena membutuhkan faktor yang lain. Berdasarkan hasil analisis, skala efikasi diri, diketahui bahwa dari semua sampel penelitian sejumlah 94 siswa kebanyakan memiliki efikasi diri yang masuk dalam kategori sedang (76\%). Ini menunjukkan bahwa efikasi diri siswa masih belum sepenuhnya memiliki efikasi diri ketika berkomunikasi yang sangat baik. Efikasi diri bisa dipengaruhi oleh pengalaman menguasai (mastery experience), modeling sosial, persuasi sosial, kondisi fisik dan emosional (Feist \& Gregory, 2010:213). Efikasi diri mengacu pada keyakinan siswa dalam berkomunikasi, sejauh mana siswa memperkirakan kemampuan dirinya dalam melaksanakan komunikasi sehingga mencapai suatu hasil (Mawanti, 2011). Efikasi diri juga mempengaruhi pada saat proses pembelajaran berlangsung (McBride, Oswald dan Beck, 2020).

Sama halnya dengan efikasi diri, keterampilan komunikasi siswa dari semua sampel penelitian sebesar 82 siswa masuk dalam kategori sedang (66\%). Keterampilan komunikasi siswa diukur secara keseluruhan dan sesuai indikator skala, dari empat indikator yaitu pertama kompetensi berkomunikasi, yang terdiri dari hal-hal yang berkaitan dengan perasaan, percaya diri, mengekpresikan ide, memberi informasi, menjelaskan dan menggunakan struktur bahasa yang baik dan benar. Kedua, hambatan komunikasi, seperti ketakutan, kecemasan, rasa malu dan selalu ingin memuaskan orang lain. Ketiga, bahasa tubuh, komunikasi non-verbal, dan keempat kematangan emosional dalam berkomunikasi, rasa saling menghormati, kepercayaan, dan toleransi antara pengirim dan penerima. Hal ini menunjukkan bahwa keterampilan komunikasi siswa belum sepenuhnya baik. Berbeda dengan penelitian Iksan et al. (2012) yang menemukan bahwa pada level mahasiswa telah mencapai keterampilan komunikasi yang baik, termasuk didalamnya keterampilan komunikasi secara lisan, tertulis dan sosial. Hal ini dapat disebabkan karena adanya perbedaan usia dan kematangan antara siswa sekolah menengah dan mahasiswa. Penelitian senada dilakukan oleh Ihmeideh, Al-Omari, \& Al-Dababneh (2010) bahwa prestasi akademik dan tingkatan kelas dapat mempengaruhi keterampilan komunikasi seseorang.

Keterampilan komunikasi meliputi mampu mengeluarkan ide dan pemikiran dengan efektif, mampu mendengarkan dengan efektif, mampu menyampaikan informasi dengan baik dan menggunakan bahasa yang baik dan efektif (Budiono \& Abdurrohim, 2020). Keterampilan komunikasi merupakan proses penyampaian informasi di mana kesuksesan komunikasi tergantung kepada desain pesan atau informasi dan cara menyampaikannya (Majid \& Rochman, 2014:194). Dengan dimilikinya keterampilan komunikasi aktivitas belajar siswa akan menjadi baik dan dapat meningkatkan kepercayaan diri yang dimiliki oleh siswa (Purnomo, 2016, Kartianti, 2019 dan Mollah, 2019). Keterampilan komunikasi dapat ditingkatkan tidak hanya dengan meningkatkan efikasi diri siswa. Masih ada faktor lain yang bisa meningkatkan keterampilan komunikasi siswa. Keterampilan komunikasi bisa ditingkatkan dengan latihan. Seperti yang dijelaskan Harapan \& Ahmad (2014:59) keterampilan komunikasi dapat dipelajari dengan mempertimbangkan hal-hal sebagai berikut: 1) keterampilan komunikasi penting untuk dikuasai; 2) mengetahui bentuk komponen perilaku yang perlu dikuasai untuk mewujudkan keterampilan komunikasi yang baik; 3) bersemangat dalam menetapkan peluang situasi-situasi yang tepat sehingga keterampilan komunikasi dapat dipraktikkan; 4) berupaya untuk meminta bantuan ketika mengalami kesulitan; 5) menghilangkan perasaan bosan dalam belajar dan berlatih; 6) pelatihan dapat dibagi dalam tahapan-tahapan agar dapat merasakan keberhasilan usaha yang dikerjakan; dan 7) mengajak teman untuk berlatih, dan 8) terus-menerus berlatih dan praktik.

Dengan adanya hasil penelitian ini, diharapkan dapat membantu guru bimbingan dan konseling atau konselor untuk meningkatkan keterampilan komunikasi siswa. Efikasi diri memiliki hubungan dengan keterampilan komunikasi siswa. Keterampilan komunikasi siswa dapat meningkat dengan adanya peningkatan efikasi diri siswa. Siswa memiliki keyakinan bahwa mereka mampu untuk berkomunikasi dengan baik sehingga dapat meningkatkan potensi yang dimiliki.

\section{PENUTUP}

Efikasi diri mempunyai hubungan positif dan signifikan dengan keterampilan komunikasi. Efikasi diri merupakan kepercayaan diri atau keyakinan seseorang untuk melakukan sesuatu. Keterampilan komunikasi tidak hanya mengandalkan kepercayaan diri atau keyakinan, dalam artian dibutuhkan latihan-latihan untuk 
meningkatkan keterampilan komunikasi siswa. Guru bimbingan dan konseling juga harus memperhatikan faktor-faktor lain yang dapat meningkatkan keterampilan komunikasi siswa atau berhubungan dengan keterampilan komunikasi. Hasil penelitian ini memberikan implikasi terhadap guru bimbingan dan konseling untuk memberikan intervensi-intervensi yang tepat agar keterampilan komunikasi siswa dapat meningkat dengan efikasi diri yang memadai. Penelitian ini dapat dijadikan sebagai rujukan bahwa salah satu faktor yang berhubungan dengan keterampilan komunikasi siswa adalah efikasi diri.

\section{UCAPAN TERIMA KASIH}

Penulis mengucapkan terimakasih kepada Direktorat Riset dan Pengabdian Masyarakat, Deputi Bidang Riset dan Pengembangan Kementerian Riset, Teknologi/Badan Riset dan Inovasi Nasional atas pemberian hibah penelitian tesis magister, dengan nomer kontrak 058/SPH/LT/DRPM/2020.

\section{DAFTAR PUSTAKA}

Akkuzu, N., \& Akkaya, N. (2014). Development and validity-reliability study of communucation skills scale for student teacher: suggestion of an alternative model. Electronic Turkish StudiesInternational Periodical For The Languages, Literature and History of Turkish or Turkic, 9(8), $111-132$.

Andriana, A. (2017). Pengaruh lingkungan sekolah terhadap minat belajar siswa kelas XI MA Wasilatul Falah Rangkasbitung. Universitas Islam Negeri Syarif Hidayatullah, Jakarta.

Ashfia, H. (2018). Efektivitas komunikasi berkualitas untuk meningkatkan efikasi diri pengasuhan anak pada orang tua sibuk. Universitas Islam Negeri Maulana Malik Ibrahim Malang. URI: http://etheses.uin-malang.ac.id/id/eprint/13733.

Aw, S. (2011). Komunikasi interpersonal. Yogyakarta: Graha Ilmu.

Azwar, S. (2017). Metode penelitian psikologi. Yogyakarta: Pustaka Pelajar.

Basuki, A. (2013). Efektivitas pelayanan konseling kelompok untuk meningkatkan keterampilan komunikasi interpersonal siswa. Jurnal Penelitian Ilmu Pendidikan, 6(1). 46-54. Doi: https://doi.org/10.21831/jpipfip.v6i1.4740.

Budiono, H \& Abdurrohim, M. (2020). Peran guru dalam mengembangkan keterampilan komunikasi (communication) siswa kelas V sekolah dasar negeri Teratai. Jurnal IKA: Ikatan Alumni PGSD UNARS, 8(1), Juni 2020. Doi: https: doi.org/1036841/pgsdunars.v8il.589.

Cangara, H. (2008). Pengantar ilmu komunikasi. Jakarta: Rajawali Pers.

Cangara, H. (2019). Pengantar ilmu komunikasi (edisi keempat). Depok: PT Rajagrafindo Persada.

Chatab, N. (2007). Profil budaya organisasi. Bandung. Penerbit Alfabeta.

Chung, Y., Yoo, J., Kim, S. W., Lee, H., \& Zeidler, D. L. (2014). Enhancing students communication skills in the science classroom through socioscientific issue. International Journal of Science and Mathematics Education, 1-27. Doi: https:doi.org/10/1007/s10763-014-9557-6.

Deviyanthi, N. M. F. S. (2016). Hubungan antara efikasi diri dengan kecemasan komunikasi dalam mempresentasikan tugas di depan kelas. Publikasi (Program Studi Psikologi Fakultas Kedokteran).

Feist, J. \& Gregory J. F. (2010). Teori kepribadian (edisi ketujuh). Jakarta: Salemba Humanika.

Friedman, H \& Meriam, S. (2016). Personality classic theories and modern research. Boston: Pearson/Allyn and Bacon.

Ghufron, N \& Risnawita, R. (2014). Teori-teori psikologi (cetakan ke 4.). Yogyakarta: AR-Ruzz Media.

Handayani, F., \& Nurwidawati, D. (2013). Hubungan self-efficacy dengan prestasi belajar siswa akselerasi. Jurnal Penelitian Psikologi, 1(2).

Handini, O., \& Soekirno, S. (2020). Hubungan efikasi diri (self-efficacy) dan pengembangan diri terhadap komunikasi antar pribadi (Penelitian pada Guru Sekolah Dasar Gugus IX Kota Surakarta). Research Fair Unistri. 4(1).

Harapan, E., \& Ahmad, S. (2014). Komunikasi antar pribadi: perilaku insani dalam organisasi Pendidikan. Jakarta: PT Rajagrafindo Persada. 
Ihmeideh, F. M., Al-Omari, A. A., \& Al-Dababneh, K. A. (2010). Attitudes toward communication skills among students'-teachers' in Jordanian Public Universities. Australian Journal of Teacher Education, 35(4), July 2010.

Iksan, Z. H, Zakariaa, E., Meerah, T. S. M., Osman, K., Lian, D. K. C., Mahmud, S. N. D., \& Krish, P. (2012). Communication skills among university students. Procedia - Social and Behavioral Sciences, 59(2012), $71-76$.

Jendra, A. F. \& Sugiyo. (2020). Pengaruh efikasi diri tehadap kecemasan presentasi siswa kelas XI di SMA Negeri 1 Wuryantoro. Journal of Guidance and Counseling, 4(1). Doi: http://dx/doiorg/10.21043/konseling.v4i1.5993.

Kamaruzzaman, K. (2016). Analisis keterampilan komunikasi interpersonal siswa. Journal Konseling Gusjigang, 2(2). Doi: https://doi.org/1023176/jkg.v2i2744.

Kartianti, M. (2019). Hubungan kepercayaan diri dengan keterampilan berkomunikasi siswa SMA. Seri Ilmu-ilmu Sosial dan Kependidikan, 3(2),71-75.

Kemendiknas. (2020). Pengembangan pendidikan budaya dan karakter bangsa. Jakarta: Kementerian Pendidikan Nasional.

Khanifah, S., Pulkan, K. K \& Sukaesih, S. (2012). Pemanfaatan lingkungan sekolah sebagai sumber belajar untuk meningkatkan hasil belajar siswa. Unes Journal of Biology Education, 1(1), 6673.

Kharisma, S. M. (2019). Hubungan antara self-efficacy dengan komunikasi interpersonal pada karyawan BPJS ketenagakerjaan. Medan: Universitas Medan Area.

Khasanah, S. U (2016). Pengaruh lingkungan sekolah terhadap kedisiplinan siswa kelas III MIN Paju Ponorogo. Skripsi. Institut Agama Islam Negeri (IAIN).

Kurniawan, R. (2013). Pengaruh lingkungan sekolah, motivasi belajar dan fasilitas belajar terhadap hasil belajar siswa pada mata pelajaran peralatan kantor kelas X administrasi perkantoran SMK Negeri 1 Kudus. Economic Education Analysis Journal, 2(3), 96-105.

Kusmiarti, R., Yuniati, I., \& Noermanzah. (2020). Improving student communication skills in learning Indonesian language through collaborative learning. International Journal of Scientific \& Technology Research, 9(01), January 2020. ISSN 2277-8616207IJSTR@2020www.Ijstr.Org.

Majid, A, \& Rochman, C. (2014). Pendekatan ilmiah dalam implementasi kurikulum 2013. Bandung: PT Remaja Rosdakarya.

Maryanti, S., Zikra, \& Nurfarhanah. (2012). Hubungan antara keterampilan komunikasi dengan aktivitas belajar siswa. Konselor, 1(2). DOI: https://doi.org/10.24036/02012112700-0-00.

Mawanti, I. (2011). Studi efikasi diri mahasiswa yang bekerja pada saat penyusunan skripsi. Skripsi. UIN Walisongo Semarang.

McBride, E., Oswald, W. W., Beck, L. A., \& Vashlishan, M. A. (2020). I'm just not that great at science': science self-efficacy in arts and communication student. Journal of Research in Science Teaching, 57(4), 597-622. Doi: https://doi.org/10.1002/tea.21604.

Mollah, M. K. (2019). Kepercayaan diri dalam peningkatan keterampilan komunikasi. El-Banat: Jurnal Pemikiran dan Pendidikan Islam, 9(1), 1-20.

Musliah, M., Purwanti, P., \& Yuline, Y. (2015). Analisis keterampilan komunikasi siswa dengan teman sebaya di sekolah menengah atas. Jurnal Pendidikan dan Pembelajaran, 4(12).

Musyafa, M. I. (2017). Hubungan antara efikasi diri dengan kecemasan komunikasi dalam bersiaran pada penyiar radio Kota Malang. Disertasi. Universitas Islam Negeri Maulana Malik Ibrahim.

Myers, B., \& Eike, R. J. (2020). The impact of servive-learning on apparel design students' selfefficacy of apparel construction, management, and communication skills. International Journal of Fashion Design, Technology and Education, 1-8. Doi:https://doi.org/10.1080/17543266.2020.1797904.

Myers, E. G. (2010). Social psychology. New York: Mc Graw-Hill.

Pal, N., Halder, S \& Guha, A. (2016). Study on communication barriers in the classroom. Journal of Communucation and Media Technologies, 6(1), 103-118.

Permana, H., Harahap, F., \& Astuti, B. (2016). Hubungan antara efikasi diri dengan kecemasan dalam menghadapi ujian pada siswa kelas IX di MTS Al Hikmah Brebes. Jurnal Hisbah, 13(1), 51-68.

Peterson, J. C., Milstein, T., Chen, Y., \& Nakazawa. (2011). Self-efficacy in intercultural communication: the development and validation of a Sojourners' Scale. Journal of International 
and Intercultural Communication, 4(4), 290-309. Doi: http://dx/doi.org/101080/17513057.2011.602476.

Purnomo, P. D. (2016). Hubungan keterampilan komunikasi interpersonal dan kepercayaan diri siswa kelas X SMAN 1 Gariam Kabupaten Blitar. Jurnal Kajian Bimbingan dan Konseling, 1(2), 5559. Doi: http://dx.doi.org./10.7977/um00lvli22016p055.

Rahmawati, E. (2014). Pengaruh lingkungan sekolah terhadap motivasi belajar siswa kelas VIII SMP Muhammadiyah 22 Pamulang. Skripsi. Universitas Islam Negeri Syarif Hidayatullah Jakarta.

Romadona, M. R. (2017). Peran efikasi diri dan kemampuan komunikasi peneliti terhadap iklim organisasi di pusat penelitian X. Jurnal Pekommas, 2(1). 55-64.

Sharifirad, G. R., Rezaeian, M., Jazini, A., \& Etemadi, Z. S. (2012). Knowledge, attitude and performance of academic members regarding effective communication skills and health promotion. Journal of Education and Health Promotion, 1(4), 8-13. Doi: 10.4103/22779531.104812.

Slavin, R. E. (2018). Educational psychology, theory and practice, $12^{\text {th }}$ Edition. New York: Pearson.

Sugiyono. (2011). Metode penelitian kuantitatif, kualitatif dan R\&D. Bandung: Alfabeta.

Suhanti, I. Y., Puspitasari, D. N., \& Noorrizki, R. D. (2018). Keterampilan komunikasi Interpersonal Mahasiswa UM. Prosiding Seminar Nasional Psikologi Klinis. 37-39.

Sumantri, M. S. (2015). Strategi pembelajaran: teori dan praktik di tingkat pendidikan dasar. Jakarta: Rajawali Press.

Suseno, M. N. (2009). Pengaruh pelatihan komunikasi interpersonal terhadap efikasi diri sebagai pelatih pada mahasiswa. Jurnal Intervensi Psikologi, l(1).

Tingginnehe, P. P., \& Wijono, S. (2018). Hubungan antara self-efficacy dengan kemampuan komunikasi pada karyawan di Hotel Pesonna Malioboro Yogyakarta. Kesmas, 7(3).

Tonglo, H. N. T. 2004. Hubungan antara efikasi diri menjalin komunikasi interpersonal dengan kemampuan menjalin komunikasi interpersonal yang efektif. Skripsi. Universitas Sanata Dharma.

Undang-Undang No. 20 Tahun 2003. Tentang Sistem Pendidikan Nasional. Bab 1 Pasal 20.

Urwani, A. N., Ramli, M., \& Ariyanto, J. (2018). Analisis dominasi komunikasi scientific pada pembelajaran sekolah menengah atas. Jurnal Inovasi Pendidikan IPA, 4(2), 181-190. doi:https://doi.org/10.21831/jipi.v4i2.21465.

Wahyuni, E. (2015). Hubungan self-effecacy dan keterampilan komunikasi dengan kecemasan berbicara di depan umum. Jurnal Komunikasi Islam, 5(1). 51-58. Doi: https://doi.org/10.15642/jki.2015.5.1.51-82.

Wardani, D. S. K. (2012). Pengaruh pelatihan komunikasi efektif untuk meningkatkan efikasi diri mahasiswa. Jurnal Psikologi dan Pendidikan dan Perkembangan, 1(2). 1-7.

Wati, M. Y., Maulidia, A. I., Irnawawi., \& Supeno. (2019). Keterampilan komunikasi siswa kelas VII SMPN 2 Jember dalam pembelajaran IPA dengan model problem based learning pada materi kalor dan perubahannya. Jurnal Pembelajaran Fisika, 8(4), 275-280. Doi: https://doi.org/10.19184/jpf.v8i4.15237.

Widiastuti, S \& Muktiani, R. N. (2010). Peningkatan motivasi dan keterampilan menggiring bola dalam pembelajaran sepak bola melalui kucing tikus pada siswa kelas 4 SD Glagahombo 2 Tempel. Jurnal Pendidikan Jasmani Indonesia, 1 . 